\title{
SYMPOSIUM ON THE EFFECTUATION OF INTER- NATIONAL LAW IN THE MUNICIPAL LEGAL ORDER
}

\section{Editorial note}

When planning Volume 4 of the Yearbook the General Editors took up the idea of composing a symposium on the effectuation of international law in the municipal legal order, consisting of a number of articles, each analysing the topic from the perspective of one specific state. Together these papers would offer a picture of the law and practice of the whole region. Unfortunately these plans have only partly materialized due to the limited time available to the persons invited to participate. The four contributions, two from East Asia, one from Southeast Asia and one from South Asia, which the Editors have been fortunate to obtain are presented in the following pages. The General Editors express the hope that they will as yet be able to commit scholars from other Asian countries to contribute papers on the subject in future Volumes of the Yearbook. 